\title{
Differentiation between first and second messenger effects of cGMP
}

\author{
Erich Schneider ${ }^{1 * \dagger}$, Sabine Wolter ${ }^{1 \dagger}$, Fanni Dittmar ${ }^{1}$, Gonzalo Fernández ${ }^{2}$, Roland Seifert ${ }^{1}$ \\ From 7th International Conference on cGMP Generators, Effectors and Therapeutic Implications \\ Trier, Germany. 19-21 June 2015
}

\section{Background}

The secondary messenger cGMP does not only play an important role in the cardiovascular system (vasodilation and inhibition of platelet aggregation), but also regulates the functions of numerous cell types like immune cells, adipocytes or neurons [1,2]. Besides its inactivation by phosphodiesterases, cGMP is exported from cells by the organic anion transporter 2 (OAT2) [3] or by multidrug-resistance proteins (MRP) [4]. Thus, cGMP may also cause effects from the extracellular side by acting as a first messenger on cell surface receptors. In fact, extracellular effects of cGMP have been described in the past. A selection of papers is listed in Table 1. A more detailed review is provided in [1].

Additionally, extracellular cGMP could be degraded by ecto-phosphodiesterases and the degradation products (GMP and guanosine) may have first messenger functions of their own. In summary, the biological functions of cGMP are much more versatile than previously acknowledged. Therefore, our project aims at differentiating between first- and second messenger functions of cGMP and the other cyclic nucleotides (cNMPs) cAMP, cUMP and $\mathrm{CCMP}$ in various cellular systems and functional readouts.

\section{Methods}

The second messenger functions of cGMP were imitated by the membrane-permeable acetoxymethyl ester analogue (cGMP-AM), which releases cGMP after intracellular hydrolysis. Unmodified cGMP was applied for the characterization of extracellular first messenger effects. In a similar way, the first- and second messenger effects of cAMP, cCMP and cUMP were characterized. As cellular models

\footnotetext{
* Correspondence: schneider.erich@mh-hannover.de

† Contributed equally

${ }^{1}$ Institute of Pharmacology, Hannover Medical School (MHH), Germany
}

Full list of author information is available at the end of the article and functional readouts we used (1) flow cytometric determination of apoptosis (annexin V/propidium iodide staining) of wildtype S49 lymphoma cells (S49 wt) and their kinase-negative counterparts (S49 kin'), (2) flow cytometric cell cycle determination of HEL (human erythroleukemia) cells, (3) ELISA-based quantitation of T-cell receptor-mediated (anti-CD3 antibody stimulation) IL-2 production of HuT-78 lymphoma cells and (4) determination of chloride flux in Calu 3 lung epithelial cells with the chloride-sensitive dye MQAE (N-(ethoxycarbonylmethyl)6-methoxyquinolinium bromide).

\section{Results}

None of the unmodified cyclic nucleotides (cAMP, cGMP, cUMP, cCMP) caused apoptosis in S49 wt or S49 kin $^{-}$cells, and the cell-permeable AMs of cAMP, cGMP and cUMP were not active either. Interestingly, guanosine, a degradation product of cGMP, induced apoptosis. Moreover, cCMP-AM exerted a surprising pro-apoptotic effect on both S49 wt and S49 kin cells. Cell cycle analysis of HEL cells revealed that cGMP-AM increased the percentage of cells in the SubG1 phase, but reduced the proportion of cells in the G2/M phase.

The $\mathrm{T}$ cell receptor-mediated IL- 2 production of HuT-78 cells was inhibited by cGMP, but not by cGMP-AM. The CFTR-mediated chloride flux in Calu 3 cells was slightly stimulated by cAMP-, cGMP- and cUMP-AM, but cCMP-AM had no significant effect. No significant stimulation of chloride flux in Calu 3 cells was observed with cell-impermeable unmodified cNMPs.

\section{Conclusions and outlook}

Our data suggest that first and second messenger functions of cGMP depend on cell type and functional readout. Thus we plan to perform further studies with a variety of model systems in order to generate a "functional profile" of first- and second messenger effects of cGMP. Moreover, 
Table 1. Examples for extracellular first messenger effects of cGMP

\begin{tabular}{lcc}
\hline Model & $\begin{array}{c}\text { extracellular cGMP } \\
\text { effect }\end{array}$ & Ref. \\
\hline rat model of colorectal pain & analgesic (oral cGMP) & {$[7]$} \\
\hline oxidative glutamate toxicity in HT22 cells & neuroprotective & {$[8]$} \\
\hline $\begin{array}{l}\text { kainate receptor-mediated } \\
\text { neurotransmitter release }\end{array}$ & inhibition & {$[9]$} \\
\hline glycine receptor-induced chloride current & $\begin{array}{c}\text { accelerates } \\
\text { desensitization }\end{array}$ & {$[10]$} \\
\hline
\end{tabular}

the surprisingly strong pro-apoptotic effect of CCMP-AM on S49 cells warrants similar studies with cyclic pyrimidine nucleotides. cCMP and cUMP now fulfil most of the criteria for second messenger functions [5]. Finally, it was recently reported that extracellular cIMP causes vasoconstriction in porcine coronary arteries [6]. Thus, cIMP should also be included in the list of potential first/second messengers and characterized more closely in future studies.

\section{Authors' details}

1 Institute of Pharmacology, Hannover Medical School (MHH), Germany. ${ }^{2}$ Current address: Dept. of Medical Biochemistry and Biophysics, Karolinska Institute, Sweden.

Published: 2 September 2015

\section{References}

1. Seifert R, Schneider EH, Bähre H: From canonical to non-canonical cyclic nucleotides as second messengers: Pharmacological implications. Pharmacol Ther 2015, 148:154-184.

2. Hofmann F, Wegener JW: cGMP-dependent protein kinases (cGK). Methods Mol Biol 2013, 1020:17-50.

3. Cropp C, Komori T, Shima JE, Urban TJ, Yee SW, More SS, et al: Organic anion transporter 2 (SLC22A7) is a facilitative transporter of cGMP. Mol Pharmacol 2008, 73(4):1151-1158.

4. Keppler D: Multidrug resistance proteins (MRPs, ABCCs): importance for pathophysiology and drug therapy. Handb Exp Pharmacol 2011, 201: 299-323.

5. Seifert R: CCMP and CUMP: emerging second messengers. Trends Biochem Sci 2015, 40:8-15.

6. Chen Z, Zhang X, Ying L, Dou D, Li Y, Bai Y, et al: cIMP synthesized by sGC as a mediator of hypoxic contraction of coronary arteries. Am J Physiol Heart Circ Physiol 2014, 307:H328-H336.

7. Silos-Santiago I, Hannig G, Eutamene H, Ustinova EE, Bernier SG, Ge P, et al: Gastrointestinal pain: unravelling a novel endogenous pathway through uroguanylin/guanylate cyclase-C/cGMP activation. Pain 2013, 154:1820-1830.

8. Albrecht P, Henke N, Tien ML, Issberner A, Bouchachia I, Maher P, et al: Extracellular cyclic GMP and its derivatives GMP and guanosine protect from oxidative glutamate toxicity. Neurochem Int 2013, 62(5):610-619.

9. Cervetto C, Maura G, Marcoli M: Inhibition of presynaptic releasefacilitatory kainate autoreceptors by extracellular cyclic GMP. J Pharmacol Exp Ther 2010, 332(1):210-219.

10. Bukanova JV, Solntseva El, Kondatenko RV, Skrebitsky VG: Glycine receptor in hippocampal neurons as a target for action of extracellular cyclic nucleotides. Neurosci Lett 2014, 561:58-63.

doi:10.1186/2050-6511-16-S1-A84

Cite this article as: Schneider et al: Differentiation between first and second messenger effects of CGMP. BMC Pharmacology and Toxicology 2015 16(Suppl 1):A84.

\section{Submit your next manuscript to BioMed Central and take full advantage of:}

- Convenient online submission

- Thorough peer review

- No space constraints or color figure charges

- Immediate publication on acceptance

- Inclusion in PubMed, CAS, Scopus and Google Scholar

- Research which is freely available for redistribution 